\title{
Detection and pathogenicity of Listeria monocytogenes in common carp (Cyprinus carpio) fish in Baghdad, Iraq
}

\author{
N.M. Al-Gburi \\ Zoonotic Diseases unit, College of Veterinary Medicine, University of Baghdad, Baghdad, Iraq, drvet2011@yahoo.com
}

(Received August 5, 2019; Accepted October 20, 2019; Available online June 12, 2020)

\begin{abstract}
A few reports are available for detection of L. monocytogenes in fish in Iraq, however, the current study was undertaken to investigate the potential role of Listeria spp. in common carp fish in Baghdad province, Iraq. A total of fresh thirty raw common carp (Cyprinus carpio) were purchased from fish sellers of various local markets in Baghdad city from (December 2017 to March 2018) The viscera was removed aseptically, the bacterial isolation and identification was conducted by a conventional culture method using Listeria selective media, biochemical tests and Vitek 2 for gram-positive. Pathogenicity of isolates was studied in vivo by inoculating mice with bacterium. Targeting virulence associated genes was used to detect the virulence and to confirm the L. monocytogenes isolates. The isolates were tested for antimicrobial susceptibility by disk diffusion method for 12 antibiotics. The results revealed that $6.66 \%$ of $L$. monocytogenes were identified from common carp fish viscera and the isolates were pathogenic in mice. L. monocytogenes virulence associated genes were detected in both isolates, while L. innocua virulence associated gene (Lin0372) was detected in one of the two isolates. The isolates were resistant to 7 out of 12 antibacterial drugs including tetracycline, ampicillin, methicillin, cefixime, oxacillin, cefotaxime and penicillin G. The results suggest that presence of L. monocytogenes in fish may have a serious role in public health hygienic in humans.
\end{abstract}

Keywords: L. monocytogenes, Lin0372, Antimicrobial susceptibility, PCR, Fish

DOI: 10.33899/ijvs.2019.125980.1205, (C) 2020, College of Veterinary Medicine, University of Mosul.

This is an open access article under the CC BY 4.0 license (http://creativecommons.org/licenses/by/4.0/).

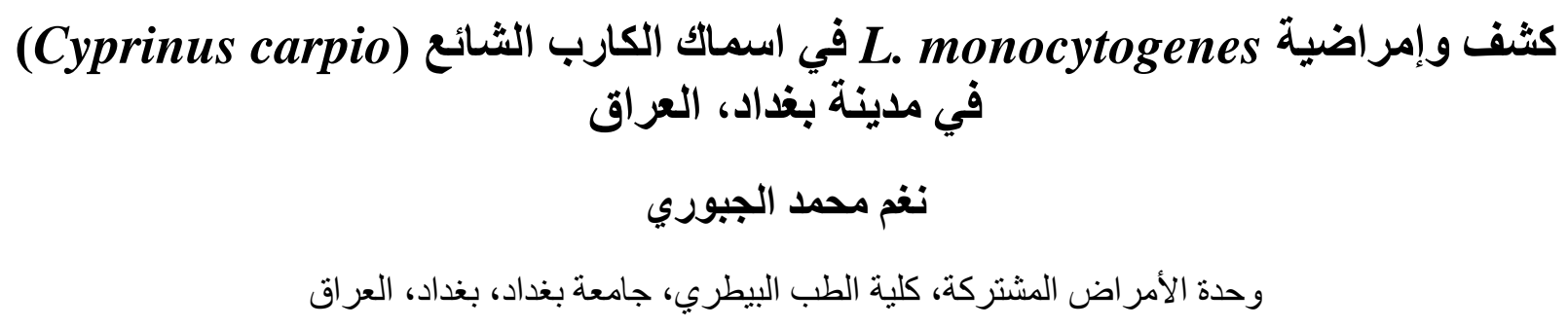

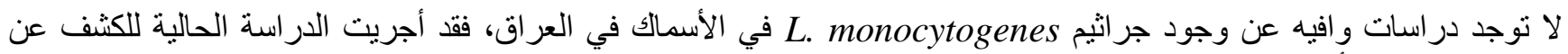

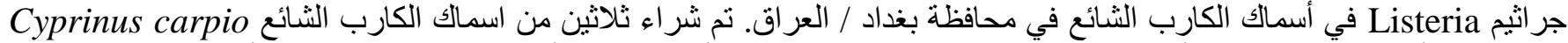

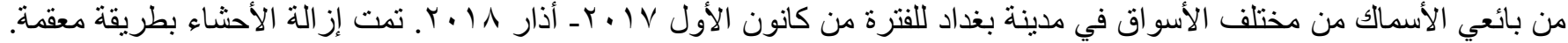

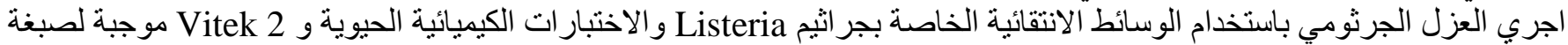

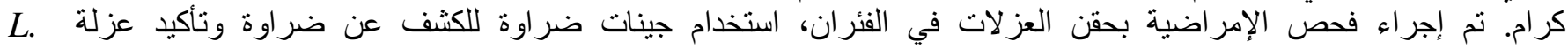
Lonocytogenes

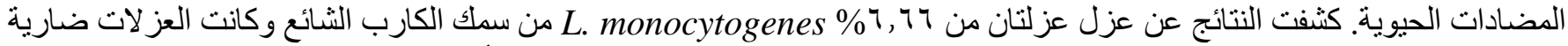
في الفئران. واد كلا العزلتين يحملان جينات الضر اوة الخاصة L. monocytogenes إلا أن واحده من العزلات كانت حامله للجين 


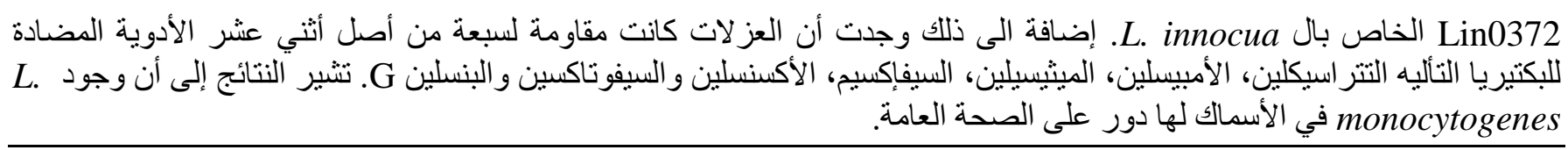

\section{Introduction}

Listeria spp. are distributed in nature, soil, sewage, dust and water, and isolated from poultry, dairy products and domestic and wild animals. L. monocytogenes is considered emerged and an important foodborne pathogen causing severe diseases in humans especially in low immune system patients, including the pregnant women, elderly and newborns $(1,2)$. Listeriosis infection has increased with increasing of ready-to-eat, heat-and-eat food product consumption. Also, Listeria spp. were isolated from food products and several studies have shown that the seafood such as fish and fish products could be contaminated with L. monocytogenes. Thus, it is considered as the important cause of a number of sporadic listeriosis caused by consumption of fish and its products (1-6). Many virulence factors have been used to detect the pathogenicity of $L$. monocytogenes, these include listeriolysin $\mathrm{O}$ (hly $\mathrm{A})$, intenrnalins (inlA, inlB), phosphatidyl-inositolphospholipase C (PI-PLC, plcA), actin (actA), virulence regulator (prfA) and Iap (invasion associated protein) $(7,8)$. $L$. monocytogenes infections in human are caused by serotypes $1 / 2 \mathrm{a}, 1 / 2 \mathrm{~b}, 1 / 2 \mathrm{c}$ and $4 \mathrm{~b}$ strains, and $4 \mathrm{~b}$ serovar is responsible for all major outbreaks of invasive listeriosis $(7,9)$. Differentiation of L. monocytogenes from other Listeria spp. may not be distinguished using conventional techniques such as selective and differential media and standard biochemical tests for differentiation of $L$. monocytogenes, $L$. innocua, $L$. ivanovii and $L$. seeligeri strains that show similar results to $L$. monocytogenes in these tests $(10,11)$. It was found that $1.4 \%$ of $L$. monocytogenes isolates were misidentified as $L$. innocua using Vitek 2 (12). Therefore, Listeria spp. confirmation must be performed by molecular methods such as polymerase chain reaction (PCR) and sequencing $(12,13)$.

Although L. monocytogenes has been reported sensitive to many antibiotics, on the other hand, it has been reported as multi-drug resistant in other studies $(7,14)$. Accordingly, this study aimed to detect and pathogenicity of $L$. monocytogenes in fish in Baghdad city, Iraq.

\section{Materials and methods}

\section{Ethical approval}

The study was carried out in the laboratory of Zoonotic Diseases unit, College of Veterinary Medicine, University of Baghdad, from Dec 2017-March 2018, and approved by the Animal Care and Use Committee (Approval No. 1788/25 Nov 2017).

\section{Isolation of Listeria}

A total of 30 fresh raw common carp (Cyprinus carpio) fish purchased from fish sellers of various local markets in Baghdad city from December 2017-March 2018were subjected to cultural and PCR methods to detect of $L$. monocytogenes. Isolation was carried out according to $(15,16)$. By using $70 \%$ ethanol and povidone-iodine fish skins were cleaned and disinfected, after that fish was opened with a sterile scalpel blade and viscera was removed to a sterile mortar and pestle containing sterile normal saline and well ground. Five $\mathrm{ml}$ of suspension were inoculated into $15 \mathrm{ml}$ Listeria enrichment broth (LEB) (Himedia) and incubated at $37^{\circ} \mathrm{C}$ for $24 \mathrm{hrs}$. Then a loopful from LEB was streaked on to PALCAM agar (Himedia and incubated at $37^{\circ} \mathrm{C}$ for $24 \mathrm{hrs}$. Colonies surrounded by a black zone on PALCAM agar plates were picked and inoculated onto HiChrome Listeria agar (Himedia) then a bluish green colony were selected and stained with Grams' stain. Further confirmation was applied by Vitek 2 Grampositive identification card.

\section{Pathogenicity in mice}

The pathogenicity of Listeria isolates in mice was investigated according to Menudier and his co-worker method (17). Briefly, the isolates were grown on trypticase soya agar plate at $37^{\circ} \mathrm{C}$ for $24 \mathrm{hrs}$. Then, 3-5 colonies were picked and homogenized with sterile normal saline and the of bacterial suspension was adjusted to McFarland tube No. 0.5 that's equal to $10^{8} \mathrm{CFU} / \mathrm{ml}$. To each isolate, three $\mathrm{Balb} / \mathrm{c}$ mice weighing $18-20 \mathrm{~g}$ were injected intraperitoneally (I/p) with approximately $5 \times 10^{7} \mathrm{CFU}$ in 0.5 $\mathrm{ml}$. Control animals were injected with $0.5 \mathrm{ml}(\mathrm{I} / \mathrm{p})$ with normal saline. The animals were observed for 7 days.

\section{Molecular identification}

The genomic DNA of the isolates was extracted according to the protocol of a commercial Wizard Genomic DNA purification Kit, Promega. PCR on 16S rRNA was applied using 27F primer (F-GAG TTT GAT CTT GGC TCA G) and 1492R primer R-TAC GGT TAC CTT GTT ACG ACT T) yielding about $1,300 \mathrm{bp} \mathrm{(18).}$

The PCR reaction mixture volume of $25 \mu \mathrm{l}$ included: (PCRpremix 12.5 $\mu$ l, forward primer $1 \mu 1$, revers primer1 $\mu$, nuclease free water $8.5 \mu \mathrm{l}$ and finally DNA $2 \mu \mathrm{l}$ ). After that the amplification was done inside thermo-cycler (BioRad, USA) using the following program: initial denaturation at $95^{\circ} \mathrm{C}$ for $5 \mathrm{~min}$ and1cyle; denaturation at $95^{\circ} \mathrm{C}$ for $30 \mathrm{sec}$ and 30 cycles; annealing at $60^{\circ} \mathrm{C}$ for $45 \mathrm{Sec}$ and 30 cycles and extension at $72^{\circ} \mathrm{C}$ for $1 \mathrm{~min}$ and 30 cycles and final 
extension at $72^{\circ} \mathrm{C}$ for $7 \mathrm{~min}$ and 1 cycle hold at 4 for $10 \mathrm{~min}$ and 1 cycle. To confirm the presence of the amplified DNA fragments, $1 \%$ agarose gel electrophoresis was performed. For sequencing, the PCR products were sent for Sanger sequencing using ABI3730XL, automated DNA sequencer by Macrogen Corporation, Korea. The similarity was applied using the Basic Local Alignment Search Tool (BLAST) in the National Center for Biotechnology Information (NCBI) for analyzing the results.

\section{PCR targeting virulence genes}

A listed of specific primers (Table 1) were used for the detection of virulence genes and to distinguish $L$. monocytogenes from L. innocua using PCR L. innocua associated genes (Lin0372, Lin0454-lin0455) and $L$. monocytogenes associated genes (prfA, actA, hlyA) were detected. The PCR reaction mixture containing a total volume of $20 \mu$ l, included: PCR (premix $10 \mu \mathrm{l}, 1 \mu \mathrm{l}$ of each forward primer and reverse primers, nuclease free water 6 $\mu \mathrm{l}$ and DNA $2 \mu \mathrm{l})$. The amplification was transported to thermo-cycler (BioRad, USA) to start the Program: initial denaturation $2 \mathrm{~min}$ at $95^{\circ} \mathrm{C}, 1$ cycles; denaturation for $30 \mathrm{sec}$ at $95^{\circ} \mathrm{C}, 35$ cycles; annealing for $45 \mathrm{sec}$ at $57^{\circ} \mathrm{C}$ for Lin0372, Lin0454-lin0455 and prfA, and annealing of actA and hly $\mathrm{A} 60^{\circ} \mathrm{C}$ for $45 \mathrm{sec}, 35$ cycles; extension $1 \mathrm{~min}$ at 72 ${ }^{\circ} \mathrm{C}$, 1cycle; final extension $7 \mathrm{~min}$ at $72{ }^{\circ} \mathrm{C}$, 1cycle; hold at $10^{\circ} \mathrm{C}$ for 10 min,1cycle. After PCR amplifycation, $1 \%$ agarosegel electrophoresis was adopted to detect the presence of amplification.

Table 1: Primers used in this study

\begin{tabular}{|c|c|c|}
\hline Primer & Sequences & Product size bp \\
\hline Lin0372-F & 5`CGTTGTTTTGGCGTTGTCGATTGTTATTG-3` & \multirow[b]{2}{*}{$1675(10)$} \\
\hline Lin0372-R & 5`TACACGATGATCTCCTGTTGCTGGTAG-3` & \\
\hline Lin0454-lin0455-F & 5'-GGATTTGGTAAATTATACAAAGGTTTTAAG-3` & \multirow{2}{*}{$849(10)$} \\
\hline Lin0454-lin0455-R & 5`TGCTTCTTGGCATTTTAGTAATCTTTC-3` & \\
\hline $\operatorname{prfA-F}$ & 5`GTATTTTTCTATATGATGGTATCACAAAGCTC-3` & \multirow{2}{*}{$540(10)$} \\
\hline PrfA-R & 5`CATATCTTTTGAGATAATCAAGATTTTGTAC-3` & \\
\hline actA-F & 5`CGCCGCGGAAATTAAAAAAAGA-3` & \multirow{2}{*}{$839(7,16)$} \\
\hline actA-R & 5`ACGAAGGAACCGGGCTGCTAG-3’ & \\
\hline hly A-F & 5-GCAGTTGCAAGCGCTTGGAGTGAA-3` & \multirow{2}{*}{$456(3,16)$} \\
\hline hlyA-R & 5-GCAACGTATCCTCCAGAGTGATCG-3` & \\
\hline
\end{tabular}

\section{Antimicrobial susceptibility test}

The L. monocytogenes isolates from carp fish were tested for susceptibility to antimicrobial drugs using disk diffusion method. Mueller-Hinton (MH) agar was used as described by Ling-ling and his co-worker method (19). Twelve antibiotics disk were used including: oxacillin $(\mathrm{Ox}, 1 \mu \mathrm{g})$, penicillin $\mathrm{G}(\mathrm{p}, 10 \mu \mathrm{g})$, Ampicillin (AMP, $25 \mu \mathrm{g}$ ), chloramphenicol $(\mathrm{C}, 10 \mu \mathrm{g})$, Methicillin (ME, $5 \mu \mathrm{g}$ ), Imipenem (IPM, $10 \mu \mathrm{g}$ ), cefixime ( $\mathrm{cFm}, 5 \mu \mathrm{g}$ ), cefotaxime

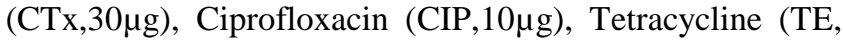
$10 \mu \mathrm{g})$, Amikacin (AK, $30 \mu \mathrm{g}$ ) and Ofloxacin (Ofx, $10 \mu \mathrm{g})$.

\section{Results}

\section{Isolation and identification}

The results revealed the isolation of only two isolate of Listeria spp. $6.66 \%$. On HiCrome Listeria agar, a bluish green colony were observed with $B$ hemolysis on blood agar. Gram positive rods, catalase positive, ferment lactose and L-rhamnose and showed CAMP test with Staphylococcus aureus giving $97 \%$ L. monocytogenes by Vitek 2.

\section{Isolates pathogenicity in mice}

The results of pathogenicity indicated that the two isolates were found to be pathogenic to mice, as all mice were dead within $72 \mathrm{hrs}$. L. monocytogenes was isolated from liver and spleen of dead animals, while control animals remained alive.

\section{Molecular identification}

The results obtained using 16S rRNA partial sequencing and analyzed using GenBank databases, showed that the first isolate had100\% homology with L. monocytogenes. While the second isolate had $99.3 \%$ homology with the corresponding genes of L. innocua strain ATCC 33090 in (NCBI).

\section{Targeting virulence associated genes}

Targeting virulence associated genes were used to detect the virulence of the isolates and to confirm isolates of $L$. monocytogenes. The first $L$. monocytogenes isolate had $L$. monocytogenes virulence-associated genes and lacked $L$. innocua virulence-associated genes that confirmed it was $L$. monocytogenes. While second isolate also had $L$. monocytogenes virulence genes and lacked $L$. innocua virulence genes except harboring to Lin0372 gene 
as shown in (Figure 1), so this confirms that the second isolate was also L. monocytogenes.

\section{Sequencing}

Partial sequences of the 16SrRNA gene of second $L$. monocytogenes strain was deposited in GenBank, with the accession numbers MH092995.1.

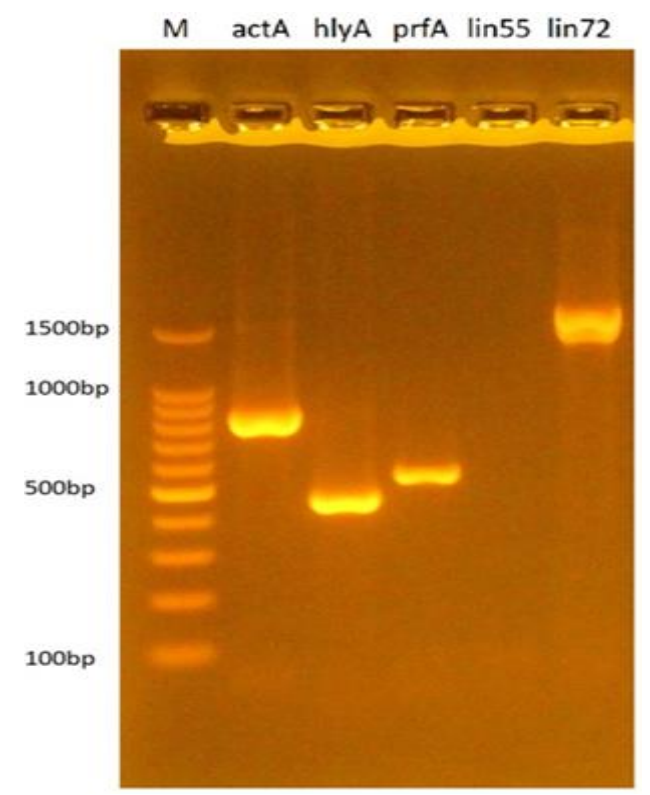

Figure 1: Agarose gel electrophoresis shows the presence of $L$. monocytogenes and $L$. innocua virulence associated genes of second L. monocytogenes isolate was fractionated on $1 \%$ agarose gel stained with Eth.Br. Lane M:100bp DNA marker. actA shows 839pb; hly 456 pb; prfA 540pb; Lin0372 (Lin72) 1675pb; Lin0454-lin0455 (Lin55) 849pb (not present).

\section{Antibacterial susceptibility test}

The L. monocytogenes isolates showed resistance to 7 out of 12 antibiotic drugs including: oxacillin, penicillin g, ampicillin, cefotaxine, cefixime, methicillin and tetracycline, while sensitive to amikacin, chloramphenicol, imipenem, ciprofloxacin and ofloxacin.

\section{Discussion}

L. monocytogenes has been reported from food products in Iraq, including meat and meat products, milk and dairy products (20-22). In fish, few reports, particularly on the molecular level are available. Our results showed that the detection of L. monocytogenes in carp fish was $6.66 \%$. Compared with other reports, Listeria spp. was isolated from $13 \%$ of frozen fish, and L. monocytogenes represented $5 \%$ in Basra city of Iraq (23). In Iran, L. monocytogenes isolate was represented $7.6 \%$ and $7.72 \%$ reported by Jamali et al and Momtaz and Yadollahi (4,24). A higher percentage reported $37.65 \%$ in fresh fish in Nigeria by Lennox et al. (25). L. monocytogenes is considered as an important human pathogen, and our results revealed that the fresh common carp contain L. monocytogenes in their viscera due to infection or normally found. Therefore, the present of L. monocytogenes in viscera of fish may lead to contaminate fish meat and then might be a source of foodborne pathogens during the processing procedure. According to culture, biochemical tests, $B$ hemolysis on blood agar, catalase positive, fermentation of both Lrhamnose and lactose and vitek 2, in addition to pathogenicity study in mice indicated that isolates were $L$. monocytogenes.

The results of 16S rRNA partial sequencing showed that the second isolate had a similarity of $99.3 \%$ with $L$. innocua ATCC 33090.After detecting the specific genes, this isolate had $L$. monocytogenes genes and lacked $L$. innocua genes Lin0454-lin0455 but had Lin0372 gene. High similarities of $99.5 \%$ and $99.9 \%$ exist between $L$. monocytegenes, $L$. innocua, L. ivanovii, $L$. seeligeri, and $L$. welshimeri. Genetic similarity is found between L. monocyto-genes serovar 4 a strains and $L$. innocua that possesses $L$. innocuaspecific genes lin0372 and lin1073. In contrast, L. innocua ATCC 33090 has no mortality in the murine intraperitoneal infection (26). Thus, this isolate is not $L$. innocua ATCC 33090 but $L$. monocytogenes and may be serovar 4a. In addition, these isolates are pathogenic due to the presence of virulence genes and causing mortality in mice. Similar results have been reported, L. monocytogenes harboring virulence genes actA, hly, prfA and plcA and generally pathogenic in vivo model of infections $(16,27,28)$.

The L. monocytogenes isolates show resistance to oxacillin, penicillin g, ampicillin, cefotaxime, cefixime, methicillin and tetracycline. L. monocytogenes isolates have been detected as multidrug resistant such as tetracycline, ampicillin, erythromycin, gentamicin, trimethoprim-sulfamethoxazole, chloramphenicol, rifampin and streptomycin $(4,29,30)$.

Other studies reported L. monocytogenes sensitivity to ampicillin, chloramphenicol, rifampin, tetracycline, gentamicin, erythromycin, vancomycin, penicillin and imipenem (31,32). Ampicillin is commonly used in the treatment of Listeria infections, and a high antibiotics resistance of $L$. monocytogenes strain, with broad used of antibiotics, thus multidrug resistant $L$. monocytogenes have been isolated from various food samples. The presence of multidrug resistant $L$. monocytogenes will have a negative impact on the public health and safety of food (18). This study indicated the presence of $L$. monocytogenes in viscera of raw common carp fish. Therefore, for public health hygiene, viscera should be removed immediately from the fish after harvesting to prevent contamination other tissues. 
Hygienic methods should be carried out during transportation and handling processing of fish and its products. In addition to conventional methods, it is necessary to use the virulence associated genes to distinguish between the Listeria spp. and to detect the pathogenic strains.

\section{Conclusion}

Our results suggest that L. monocytogenes isolated from fish have the potential role in public health hygienic in humans.

\section{Acknowledgments}

The author would like to thank Assist Professor Dr. Inam Jassim for Molecular identification part, and to Dr. Nawal Dhahd Mahmood for helping in the laboratory.

\section{Conflict of interest}

None, there is any conflict of interest.

\section{References}

1. Thomas M, Vriezen R, Farber J, Currie A, Schlech W, Fazil A. Economic cost of a Listeria monocytogenes outbreak in Canada, 2008. Foodbone. Pathol Dis. 2015;12:966-971. 10.1089/fpd.2015.1965

2. Elbashir S, Parveen S, Schwarz J, Rippen JT, Jahncke M, DePaola A. Seafood pathogens and information on antimicrobial resistance: A review. Food Microbiol. 2018;70:85-93. 10.1016/j.fm.2017.09.011

3. Skowron K, Wiktorczyk N, Grudlewska K, Wałecka-Zacharsk E, PaluszakZ., Kruszewski S, \& Gospodarek-Komkowska E. Phenotypic and genotypic evaluation of Listeria monocytogenes strains isolated from fish and fish processing plants. Ann Microbiol. 2019;69(5):469482. https://doi.org/10.1007/s13213-018-1432-1

4. Jamali H, Paydar M, Ismail S, Looi CY, Wong WF, Radmehr B, Abedini A. Prevalence, antimicrobial susceptibility and virulotyping of Listeria species and Listeria monocytogenes isolated from open-air fish markets. BMC Microbiol. 2015;15:144. 10.1186/s12866-015$\underline{0476-7}$

5. Lassen GS, Ethelberg S, Bjorkman JT, Jensen T, Sorensen G, Kvistholm JA, Muller L, Nielsen EM, Molbak K. Two Listeria outbreaks caused by smoked fish consumption-using whole-genome sequencing for outbreak investigations. Clin Microbiol Infect. 2016;22(7):620-4. 10.1016/j.cmi.2016.04.017

6. Schjorring S, Gillesberg LS, Jensen T, Moura A, Kjeldgaard JS, Muller L. Cross-border outbreak of listeriosis caused by cold-smoked salmon, revealed by integrated surveillance and whole genome sequencing (WGS), Denmark and France, 2015 to 2017. Euro Surveill. 2017;22(50):17-00762. 7917.ES.2017.22.50.17-00762

7. Soni DK, Singh M, Singh DV, Dubey SK. Virulence and genotypic characterization of Listeria monocytogenes isolated from vegetable and soil samples. BMC Microbiol. 2014;14:241. 10.1186/s12866-014$\underline{0241-3}$

8. Wu S, Wu Q, Zhang J, Chen M, Guo W. Analysis of multilocus sequence typing and virulence characterization of Listeria monocytogenes isolates from Chinese retail ready-to-eat food. Front Microbiol. 2016;7:168. 10.3389/fmicb.2016.00168
9. Salcedo C, Arreaza L, Alcala B, De La Fuente L, Vazquez J. Development of a multilocus sequence typing method for analysis of Listeria monocytogenes clones. J Clin Microbiol. 2003;41:757-62. $10.1128 / \mathrm{jcm} .41 .2 .757-762.2003$.

10. Johnson J, Jinneman K, Stelma G, Smith BG, Lye D, Messer J, Ulaszek J, Evsen L, Gendel S, Bennett RW, Swaminathan B, Pruckler J, Steigerwalt A, Kathariou S, Yildirim S, Volokhov D, Rasooly A, Chizhikov V, Wiedmann M, Fortes E, Duvall RE, Hitchins AD. Natural atypical Listeria innocua strains with Listeria monocytogenes pathogenicity island 1 genes. Appl Environ Microbiol. 2004;70(7):4256-66. 10.1128/AEM. 70.7.4256-4266.2004.

11. Moreno LZ, Renata P, Debora DS, Daniele CR, Thais SP, Ferreira AM, Ernesto H, Cristhiane M F, Glavur RM, Maria H. Phenotypic and genotypic characterization of atypical Listeria monocytogenes and Listeria innocua isolated from swine slaughterhouses and meat markets. Res Microbiol. 2012;163(4):268-71. 10.1155/2014/742032.

12. De Lappe N, Ciara L, Jean OC, Martin C. Misidentification of Listeria monocytogenes by the Vitek 2 System. J Clin Microbiol. 2014;52(9):3494-3495. 10.1128/JCM.01725-14.

13. Leong D. Monitoring, understanding and controlling Listeria in food processing [PhD thesis]. Ireland: Department of Agriculture, Food and the Marine, University College Cork; 2017. 25-29 p.

14. Pelissier MR, Mendes SD, Sutherland AD, Batista CR. Detection of Listeria monocytogenes species in refrigerated chicken carcasses using ClearviewTM and a modified conventional culturing method. Braz J Microbiol. 2001;32(2):113-116. 10.1590/S151783822001000200008.

15. Srinivasan V, Nam HM, Nguyen LT, Tamilselvam B, Murinda SE, Oliver SP. Prevalence of antimicrobial resistance genes in Listeria monocytogenes isolated from dairy farms. Foodborne Pathol Dis. 2005;2:201-211. 10.1089/fpd.2005.2.201.

16. Nayak DN, Savalia CV, Kalyani H, Kumar R, Kshirsagar DP. Isolation, identification, and characterization of Listeria sp. from various animal origin foods. Vet World. 2015;8(6):695-701. 10.14202/vetworld.2015.695-701.

17. Menudier A, Bosiraud C, Nicolas JA. Virulence of Listeria monocytogenes serovars and Listeria $\mathrm{sp}$. in experimental infection of mice. J Food Prot. 1991;54:917-921. 10.4315/0362-028X-54.12.917.

18. Mukherjee S, Kumar D, Nanda AK, Chakraborty R. 16S rRNA gene sequence analyses of the metagenome derived from waters of river Mahananda at Siliguri: An approach to understand bacterial diversity. Indian J Biotechnol. 213;12:80-808. http://nopr.niscair.res.in/handle/123456789/16526

19. CLSI (Clinical and Laboratory Standards Institute). Performance Standards for Antimicrobial Susceptibility Testing, Twenty-Fourth Informational Supplement. CLSI document M100-S24. Wayne, PA.2014.

20. Al-Brefkani AMT and Ismaeil M A M. "Characterisation of Listeria monocytogenes from Food and Human Clinical Samples at Duhok, Kurdistan Region of Iraq. J Pure Appl Microbiol. 2019;13(4):22152226. https://doi.org/10.22207/JPAM.13.4.35.

21. Ahmed SS, Taye BH, Ameen AM, Merza SM, Sharif YH. Isolation and molecular detection of Listeria monocytogenes in minced meat, frozen chicken and cheese in Duhok province, Kurdistan region of Iraq. J Food Microbiol Saf Hyg. 2017;2(1):1-4. 10.4172/24762059.1000118

22. Al-Dabbagh SY. Diagnostic study for Listeria monocytogenes isolated from brain and meat of sheep in Mosul city. Iraqi $\mathrm{J}$ Vet Sci. 2019;33(2):51-55. 10.33899/ijvs.2019.163087.

23. Al-Maliki JGM. Prevalence of Listeria monocytogenes in frozen fish in Basrah city markets. Basrah J Vet Res. 2010;10:127-132.

24. Momtaz H, Yadollahi S. Molecular characterization of Listeria monocytogenes isolated from fresh seafood samples in Iran. Diagn Pathol. 2013;8(149):1-6. 10.1186/1746-1596-8-149

25. Lennox JA, Etta PO, John GE, Henshaw EE. Prevalence of Listeria monocytogenes in fresh and raw fish, chicken and beef. J Advan Microbiol. 2017;3(4):1-7. 10.9734/JAMB/2017/33132 
26. Jianshun $\mathrm{C}$, Lingli J, Xueyan $\mathrm{C}$, Xiaokai L, Yang C, Ying $\mathrm{Y}$, Guoming T, Dongyou L. Weihuan F. Listeria monocytogenes serovar $4 \mathrm{a}$ is a possible evolutionary intermediate between $L$. monocytogenes serovars $1 / 2 \mathrm{a}$ and $4 \mathrm{~b}$ and $L$. innocua. J Microbiol Biotechnol. 2009;19(3):238-249. 10.4014/jmb.0805.304

27. Kaur S, Malik SVS, Bhilegaonkar KN, Vaidya VM, Barbuddhe SB. Use of a phospholipase $\mathrm{C}$ assay, in vivo pathogenicity assays and PCR in assessing the virulence of Listeria spp. Vet J. 2009;184:366-370. 10.1016/j.tvjl.2009.03.032

28. Negia M, Deepak BR, Jess V, Pankaj D, Deepthi V, Vysakh M, Rahul S, Satya VS, Ashok K, Sukhadeo BB, Wasudeo R. Isolation and Identification of pathogenic Listeria monocytogenes from diarrheal cases in human infants and young animals. Advan Anim Vet Sci. 214;2(5S):5. 10.14737/journal.aavs/2014/2.5s.5.10

29. Fallah AA, Saei-Dehkordi SK, Mahzounieh M. Occurrence and antibiotic resistance profiles of Listeria monocytogenes isolated from seafood products and market and processing environments in Iran. Food Control. 2013;34:630-636. 10.1016/j.foodcont.2013.06.015

30. Noll M, Sylvia K, Al Dahouk S. Antibiotic susceptibility of 259 Listeria monocytogenes strains isolated from food, food-processing plants and human samples in Germany. J Infect Public Health. 2018;11(4):572-577. 10.1016/j.jiph.2017.12.007

31. Ramanjeneya S, Sahoo SC, Pathak R1, Kumar M, Vergis J, Malik SV, Barbuddhe SB, Rawool DB. Virulence potential, biofilm formation, and antibiotic susceptibility of Listeria monocytogenes isolated from cattle housed in a particular gaushala (cattle shelter) and organized farm. Foodborne Pathog Dis. 2019;16(3):214-220. 10.1089/fpd.2018.2494

32. Cao X, Wang Y, Wang Y, Ye C. Isolation and characterization of Listeria monocytogenes from the black-headed gull feces in Kunming. J Infect Public Health. 2018;11(1):59-63. 10.1016/j.jiph.2017.03.003 